\title{
Chemical composition of sage (Salvia officinalis L.) essential oil from the Rio de Janeiro State (Brazil)
}

PORTE, A. ${ }^{1^{*}}$; GODOY, R.L.O. ${ }^{2}$; MAIA-PORTE, L.H. ${ }^{3}$

${ }^{1}$ Departamento de Tecnologia de Alimentos, Escola de Nutrição, Universidade Federal do Estado do Rio de Janeiro (UNIRIO). Rua Dr. Xavier Sigaud, 290, Urca, Cep 22290-180, Rio de Janeiro, Brasil. e-mail: *alexandre

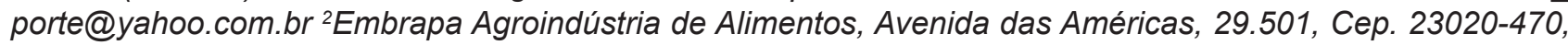
Rio de Janeiro, Brasil. ${ }^{3}$ Instituto Multidisciplinar, Rua Governador Roberto da Silveira, s/no, Cep. 26020-740, Universidade Federal Rural do Rio de Janeiro (UFRRJ), Nova Iguaçu, Brasil.

\begin{abstract}
The purpose of this study was to investigate the chemical composition of the essential oil from fresh leaves of sage (Salvia officinalis L.) from Petrópolis, Rio de Janeiro State, for international trade. The oil was isolated by hydrodistillation in a Clevenger-type apparatus and analyzed through a combination of GC-FID and GC-MS. The yield was $2.3 \%$ on dry basis. Forty-seven constituents were identified according to their chromatographic retention indices and mass spectra, corresponding to $94.90 \%$ of the compounds present. The major constituents of the oil were $\alpha$-thujone $(40.90 \%)$, camphor $(26.12 \%), \alpha$-pinene $(5.85 \%)$ and $\beta$-thujone $(5.62$ $\%)$. The essential oil studied was similar to those found in several European countries and can be a valuable product for the small farmers from the Petrópolis region in Rio de Janeiro State.
\end{abstract}

Keywords: Lamiaceae, Salvia officinalis, essential oil

RESUMO: Composição química do óleo essencial de Salvia (Salvia officinalis) do Estado do Rio de Janeiro (Brasil). O objetivo deste estudo foi investigar a composição química do óleo essencial de folhas de sálvia (Salvia officinalis L.) de Petrópolis, Rio de Janeiro, para o comércio internacional. $\mathrm{O}$ óleo foi isolado por arraste a vapor em aparelho de Clevenger e analisado por CG-DIC e CG-EM. O rendimento foi de 2,3\% em base seca. Quarenta e sete substâncias foram identificadas de acordo com seus índices de retenção e espectros de massas, correspondendo a $94,90 \%$ dos compostos presentes no óleo. Os principais constituintes do óleo foram $\alpha$-tujona $(40,90 \%)$, cânfora $(26,12 \%)$, $\alpha$-pineno (5,85 \%) e $\beta$-pineno $(5,62 \%)$. O óleo estudado foi similar àqueles encontrados em vários países europeus e pode ser um valioso produto para pequenos produtores da região de Petrópolis no Estado do Rio de Janeiro.

Palavras-chave: Lamiaceae, Salvia officinalis, óleo essencial

\section{INTRODUCTION}

Salvia officinalis or sage (Lamiaceae family) is a perennial low shrub native of the Mediterranean region and its family reported to include more than 900 species (Pierozan et al. 2009; Ilkiu-Vidal et al. 2010). Its essential oil is added to meat, sausage, poultry stuffings, fish, soups, canned foods and other food products. Sage essential oil protected liver patés from oxidation processes and could be used as alternative option to synthetic antioxidants such BHT and was used in dry fermented buffalo sausage too (Estévez et al. 2007; Salem \& Ibrahim, 2010).

Sage essential oil is also effective against several bacteria, e.g., Listeria monocytogenes (1 $\mathrm{ml}$ essential oil : $1 \mathrm{ml}$ 96\% ethanol), Bacillus cereus
(0,5 mL of essential oil), Bacillus subtilis $(0,5 \mathrm{~mL}$ of essential oil), Escherichia coli $(0,5 \mathrm{~mL}$ of essential oil) and Staphylococcus aureus $(0,5 \mathrm{~mL}$ of essential oil), all recognized foodborne pathogens (VeliӨkovic et al. 2003; Radulescu et al. 2004; Mitić-Culafić et al. 2005; Estévez et al. 2007; Delamare et al. 2007; Klaus et al. 2009). However, antimicrobial activity (6,4 mg essential oil : $1 \mathrm{ml}$ methanol) was not observed against Staphylococcus aureus in recent study (Pozzo et al. 2011).

The sage oil from Dalmatia region (Croatia), has been widely examined from the early 1960s until recent years. Traditionally, it is highly appreciated and economically valued. The plant is both, cultivated

Recebido para publicação em 29/08/2011

Aceito para publicação em 23/01/2013

Rev. Bras. PI. Med., Campinas, v.15, n.3, p.438-441, 2013. 
and collected in Turkey, Italy, Greece, France and Spain and serves as the standard sage to which others are compared (Svoboda \& Deans, 1992). Although Salvia sp. is not originally from Brazil, some species have been well adapted, especially in Rio de Janeiro State.

The purpose of this paper was to examine the composition of the essential oil of Salvia officinalis from Rio de Janeiro State, Brazil for international trade.

\section{MATERIALS AND METHODS}

The botanical material (variety "Elephant Ear") was collected in city of Petrópolis, Rio de Janeiro State, Brazil, directly from irrigated plots to trade of a small farmer. A voucher specimen of this plant was deposited in the herbarium of the Botanical Department of the Biology Institute of the Federal Rural University of the Rio de Janeiro (RBR 4240).
The plants were collected during the flowering phase (December/2008).

Five hundred grams of fresh leaves were submitted to hydrodistillation (with approximately $400 \mathrm{~mL}$ of water) in a Clevenger-type apparatus for 72 minutes without collecting solvent (Porte \& Godoy, 2008). The extractions were performed in duplicates. The yield on dry basis was calculated from Equation 1:

EQUATION 1. Obtaining of essential oil yield on dry basis

$$
Y(\%)=100 \cdot \frac{E O M}{S M-W M}
$$

Where:

$\mathrm{Y}=$ Yield on dry basis

EOM = Essential Oil Mass obtained

$\mathrm{SM}=$ Sample Mass (fresh leaves mass)

WM $=$ Water Mass (AOCS, 2009)

TABLE 1. Chemical composition of the essential oil from leaves of Salvia officinalis L. from Rio de Janeiro, Brazil.

\begin{tabular}{|c|c|c|c|c|c|c|c|}
\hline Compounds & $\mathbf{R} \mathbf{I}^{1}$ & $\mathrm{KI}^{2}$ & $\%$ & Compounds & $\mathbf{R I}$ & KI & $\%$ \\
\hline$\alpha$-Thujone & 1102 & 1102 & 40.90 & (E)- $\beta$-Ocimene & 1041 & 1040 & 0.10 \\
\hline Camphor & 1142 & 1143 & 26.12 & Myrtenol & 1193 & 1194 & 0.10 \\
\hline$\alpha$-Pinene & 938 & 939 & 5.85 & (Z)- $\beta$-Ocimene & 1041 & 1040 & 0.10 \\
\hline$\beta$-Thujone & 1116 & 1114 & 5.62 & $\alpha$-Gurjunene & 1409 & 1409 & $t^{3}$ \\
\hline Camphene & 953 & 953 & 3.43 & allo-Aromadendrene & 1461 & 1461 & $\mathrm{t}$ \\
\hline 1,8-Cineole & 1032 & 1033 & 1.93 & $\beta$-Bourbonene & 1384 & 1384 & $\mathrm{t}$ \\
\hline Limonene & 1030 & 1031 & 1.86 & Carvenone & 1252 & 1252 & $\mathrm{t}$ \\
\hline$\alpha$-Humulene & 1454 & 1454 & 1.40 & Carvone & 1242 & 1242 & $\mathrm{t}$ \\
\hline Borneol & 1165 & 1165 & 1.07 & Carvotanacetone & 1246 & & $\mathrm{t}$ \\
\hline Myrcene & 992 & 991 & 1.03 & Caryophyllene alcohol & 1568 & 1568 & $\mathrm{t}$ \\
\hline$\beta$-Caryophyllene & 1418 & 1418 & 0.80 & Cyperene & 1398 & 1398 & $\mathrm{t}$ \\
\hline$\beta$-Pinene & 979 & 980 & 0.67 & $\sigma$-Cadinene & 1524 & 1524 & $\mathrm{t}$ \\
\hline Tricyclene & 926 & 926 & 0.62 & $(E)-\beta$-Guaiene & 1500 & 1500 & $\mathrm{t}$ \\
\hline$\alpha$-Terpinolene & 1088 & 1088 & 0.53 & $(E)$-Verbenil acetate & 1292 & 1292 & $\mathrm{t}$ \\
\hline Endobornil acetate & 1285 & 1285 & 0.52 & $\gamma$-Gurjunene & 1473 & 1473 & $\mathrm{t}$ \\
\hline$\gamma$-Terpinene & 1061 & 1062 & 0.49 & $p$-Cimenene & 1089 & 1089 & $\mathrm{t}$ \\
\hline Terpinen-4-ol & 1176 & 1177 & 0.49 & Piperitone & 1252 & 1252 & $\mathrm{t}$ \\
\hline (Z)-Salvene & 856 & 855 & 0.30 & Sabinene hidrate acetate & 1253 & 1253 & $\mathrm{t}$ \\
\hline$\alpha$-Terpinene & 1018 & 1018 & 0.23 & Verbenone & 1204 & 1204 & $\mathrm{t}$ \\
\hline$p$-Cymene & 1026 & 1026 & 0.19 & Viridiflorene & 1493 & 1493 & $\mathrm{t}$ \\
\hline$\alpha$-Thujene & 930 & 931 & 0.18 & (Z)- $\beta$-Guaiene & 1490 & 1490 & $\mathrm{t}$ \\
\hline Thymol & 1291 & 1290 & 0.14 & (Z)-Calamenene & 1521 & 1521 & $\mathrm{t}$ \\
\hline$\alpha$-Terpineol & 1188 & 1189 & 0.13 & (Z)-Carveol & 1229 & 1229 & $\mathrm{t}$ \\
\hline$\alpha$-Phellandrene & 1005 & 1005 & 0.10 & & & & \\
\hline
\end{tabular}

Total (\%)

1. $\mathrm{RI}=$ retention index experimental determined (medium value of duplicates)

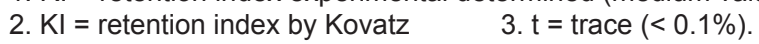


Chemical analysis was performed on a Hewlett-Packard 5890 series II gas chromatograph fitted with an HP-5 capillary column $(25 \mathrm{~m} \times 0.20$ $\mathrm{mm}, 0.33 \mu \mathrm{m}$ film thickness). The carrier gas was hydrogen at a flow of $1 \mathrm{~mL} \mathrm{~min}^{-1}$, and split ratio 1:100. The oven temperature was programmed from $60-25$ ${ }^{\circ} \mathrm{C}$ at $2^{\circ} \mathrm{C} \mathrm{min}{ }^{-1}$, the injector temperature was $25^{\circ} \mathrm{C}$ and the detector (FID) temperature was $28^{\circ} \mathrm{C}$ (Porte \& Godoy, 2008).

The analysis was carried out on a Hewlett Packard 5890 series II gas chromatograph coupled to an HP 5970 mass selective detector using a fused silica capillary column HP-5 $(25 \mathrm{~m} \times 0.20 \mathrm{~mm}$, film $0.33 \mathrm{~mm}$ thickness). The column temperature was programmed from $60^{\circ}-250^{\circ} \mathrm{C}$ at $2^{\circ} \mathrm{C} \mathrm{min}{ }^{-1}$, with helium as the carrier gas at a flow rate of $1 \mathrm{~mL} \mathrm{~min}^{-1}$. The ion source temperature was $300^{\circ} \mathrm{C}$ and the electron energy $70 \mathrm{eV}$. Identification of components was based on comparison of their mass spectra with those found in the literature, on retention indices and mass spectrometry data bank (NIST) and computer search Wiley library (Adams, 2007; Porte \& Godoy, 2008).

\section{RESULTS AND DISCUSSION}

The yield of sage essential oil from Rio de Janeiro was $2.3 \%$ on dry basis. This is in accordance with others values found in literature, which reported yields of 1.1 to $2.8 \%$ (Couladis et al. 2002; Velièkovic et al. 2003; Lima et al. 2004; Klaus et al. 2009).

The compounds identified in the oil sample are presented in Table 1.

GC and GC/MS analysis of the oil resulted in the identification of 47 constituents, which account for $94.90 \%$ of the oil. Its chemical composition is characterized by high amounts of $\alpha$-thujone, camphor, $\beta$-pinene and $\alpha$-pinene, and is similar to those found in the oils from Italy (Veličkovic et al. 2003), Romania (Veličkovic et al. 2003; Radulescu et al. 2004), Serbia and Montenegro (Couladis et al. 2002; Mitić-Culafić et al. 2005), Brazil (Pierozan et al. 2009) and Turkey (Karaaslan \& Özguven, 2001).

This suggests that the sage essential oil from Rio de Janeiro could have desirable chemical characteristics for international trade due to the similar concentrations of its major constituents in accordance to the essential oils from Dalmatia, the more recognized source of $S$. officinalis essential oil (Lima et al. 2004).

Furthermore, the essential oil studied could have good properties for therapeutic treatment of coughs and unspecific irritations of the respiratory tract and as an efficient agent against several foodborne pathogenes, as yeasts, molds and gram-positive bacteria, because of its high content of camphor.

If compared with literature and international standards cited by literature, the essential oil of Salvia officinalis from Petrópolis, Rio de Janeiro State, Brazil can be a valuable product for the small farmers that region. The next step will be to evaluate the chemical composition of essential oil from Salvia officinalis during all seasons to check the variation of the major components of essential oil and finally to compose the profile of the essential oil.

\section{ACKNOWLEDGMENTS}

We are grateful to CAPES for the financial support.

\section{REFERENCE}

ADAMS, R.P. Identification of essential oil components by gas chromatography/ mass spectroscopy. 4 ed. Illinois: Allured Publishing Corporation, Carol Stream, 2007. 804 p.

AMERICAN OIL CHEMIST'S SOCIETY. Official Method. Moisture Distillation Method (Da 2b-42), New York: AOCS, 2009.

COULADIS, M. et al. Essential oil of Salvia officinalis $L$. from Serbia and Montenegro. Flavour and Fragrance Journal, v. 17, n. 2, p. 119-26, 2002.

DELAMARE, A.P.L. et al. Antibacterial activity of the essential oils of Salvia officinalis L. and Salvia triloba L. cultivated in South Brazil. Food Chemistry, v. 100, p. 603-8, 2007.

ESTÉVEZ, M. et al. Sage and rosemary essential oils versus $\mathrm{BHT}$ for the inhibition of lipid oxidative reactions in liver pâté. Lebensmittel-Wissenschaft undTechnologie, v. 40, p. 58-65, 2007.

ILKIU-VIDAL, L.H. et al. Ação de potenciais hidrogeniônicos no crescimento e produtividade de sálvia (Salvia officinalis L.). Revista Brasileira de Plantas Medicinais, v. 12, n. 1, p. 43-7, 2010.

KARAASLAN, D.; ÖZGUVEN, M. Determination of qualitative and quantitative features of sage (Salvia officinalis L.) essential oils. Pakistan Journal of Biological Sciences, v. 4, n. 1, p. 41-3, 2001.

KLAUS, A. et al. Antibacterial activity of aromatic plants essential oils from Serbia against the Listeria monocytogenes. Journal of Agricultural Sciences, v. 54, n. 2, p. 95-104, 2009.

LIMA, C.F. et al. Evaluation of toxic/protective effects of the essential oil of Salvia officinalis on freshly isolated rat hepatocytes. Toxicolology in Vitro, v. 18, p. 45765, 2004.

MITIĆ-CULAFIĆ, D. et al. Comparative study on the antibacterial activity of volatiles from sage (Salvia officinalisL.) Archives of Biological Sciences, v. 57, n. 3, p. 173-8, 2005.

PIEROZAN, M.K. et al. Chemical characterization and antimicrobial activity of essential oils of Salvia L. species. Ciencia e Tecnologia de Alimentos, v. 29, n. 4, p. 764-70, 2009.

PORTE, A.; GODOY, R.L.O. Chemical composition of Thymus vulgaris L. (thyme) essential oil from the Rio de Janeiro State (Brazil). Journal of the Serbian Chemical Society, v. 73, n. 3, p. 307-10, 2008.

Rev. Bras. PI. Med., Campinas, v.15, n.3, p.438-441, 2013. 
POZZO, M. et al. Atividade antimicrobiana de óleos essenciais de condimentos frente a Staphylococcus spp isolados de mastite caprina. Ciência Rural, v. 41, n. 4, p. 667-72, 2011.

RADULESCU, V. et al. Capillary gas chromatographymass spectrometry of volatile and semi-volatile compounds of Salvia officinalis. Journal of Chromatography A, v. 1027, p. 121-6, 2004.

SALEM, F.M.A.; IBRAHIM, H.M. Dry fermented buffalo sausage with sage oil extract: Safety and quality.
Grasas y aceites, v. 61, n. 1. p. 76-85, 2010.

SVOBODA, K.P.; DEANS, S.G. A study of the variability of rosemary and sage and their volatile oils on the British market: their antioxidative properties. Flavour and Fragrance Journal, v. 7, n. 2, p. 81-7, 1992.

VELIČKOVIC, A.S. et al. The possibilities of the application of some species of sage (Salvia L.) as auxiliaries in the treatment of some diseases. Journal of the Serbian Chemical Society, v. 68, n. 1, p. 43545, 2003. 